\title{
MODIFIED TECHNIQUES IN QUANTIFICATION OF INTRACELLULAR LISTERIA MONOCYTOGENES IN VITRO INFECTION
}

\author{
Tran Thanh Thao ${ }^{1,2, \bowtie}$, Nguyen Thi $\mathrm{Ha}^{1}$ \\ ${ }^{I}$ Can Tho University \\ ${ }^{2}$ Diamantina Institute, Faculty of Medicine, University of Queensland, Australia \\ ${ }^{\square}$ To whom correspondence should be addressed. E-mail: tthanhthao@ctu.edu.vn
}

Received: 03.8.2019

Accepted: 27.12.2019

SUMMARY

\begin{abstract}
The demand for reliable methods for the quantification of intracellular bacteria is growing. Among modern methods such as PCR and flow cytometry, traditional methods including colony forming unit assay and immune-fluorescence are still the two most commonly techniques worldwide. In colony forming unit assay, there are variations among publications, making data results inconsistent across studies. The aim of this paper is to evaluate available techniques and develop improved protocols for the quantification of intracellular Listeria monocytogenes (LM) in vitro infection assay. This study has suggested different uptake time for phagocytic and non-phagocytic cells. Specifically, uptake time was determined at 0.5 hour after infection for RAW264.7 macrophages and 2 hours for L929 fibroblast host cells. To efficiently remove extracellular bacteria during infection period, gentamicin at high and low concentrations was used during the infection assay. High concentration of gentamicin was used to kill extracellular bacteria while low concentration of gentamicin was used to prevent secondary infection of host cells during the infection period. To obtain a more accurate number of alive LM from a large scale experiment, phosphate-buffered saline/PBS should be used rather than mili-Q (mQ) water to lyse the host cell as $\mathrm{mQ}$ water can kill additional bacteria unexpectedly. In immune-fluorescence, LM can be visualized by using either the LM expressing green fluorescence protein (GFP) or antibody against LM. To observed GFP signal, cells should be fixed with paraformaldehyde as methanol will rapidly dim the GFP signal. Findings from this study will benefit researchers engaged in both basic cell biology and infectious diseases.
\end{abstract}

Keywords: bacteria, colony forming unit, intracellular, Listeria monocytogenes, macrophages

\section{INTRODUCTION}

Listeria monocytogenes (LM) is a gram positive food-borne intracellular bacterium. Healthy people once infected by LM usually got mild to severe gastroenteritis. However, in immune-compromised and susceptible individuals including the elderly, the new-born and pregnant women, very low numbers of ingested bacteria (from $10^{2}$ to $10^{4}$ ) can cause listeriosis. The life-threatening listeriosis can lead to systemic infection followed by meningitis. In addition, listeriosis in pregnant women might cause abortion or fetal complications. Despite rarely occurrence, listeriosis is responsible for up to 20 $30 \%$ of mortality in vulnerable patients (de Noordhout et al., 2014). Particularly, LM can survive under food storage conditions, such as cold temperature $\left(4^{\circ} \mathrm{C}\right)$, high $\mathrm{pH}$ and high salted levels
(Cossart, 2011), which makes this bacterium as an alarming food pathogen (Ferreira et al., 2016).

LM can infect various cell types from nonphagocytic cells (epithelial cells, hepatocytes, endothelial cells, fibroblasts) to phagocytic cells (monocytes, macrophages, neutrophils) (Hamon et al., 2006). Inside the host cells, LM express multiple virulence factors that allow them to escape host vacuoles, replicate intracellularly and spread to neibouring cells (Vázquez-Boland et al. 2001).

As LM is an easily-grown bacterium and its pathogenicity has provided a plenty of useful knowledge of host-pathogen interaction, studying pathogenesis of LM during its intracellular invasion of host cells has become a special interest to immunologists (Becattini et al., 2017). 
Quantification of intracellular LM is an important step, which allowing an overview of host cell capability to deal with this professional bacterium during phagocytosis. The advent of molecular tools allows the enumeration of intracellular LM to be performed by several approaches, including colony-forming unit (CFU) on agar plates (Portnoy et al., 1988), immunofluorescent staining of LM (Drevets, Campbell, 1991), PCR methods (qPCR and dPCR) (Traunšek et al., 2011; Ricchi et al., 2017) and flow cytometric quantification of intracellular bacteria (Swarts et al.,1998). Of those, the first two methods are mostly used in published studies, probably due to their cost-effectiveness and visual data presentation. Although CFU performance is a standard and popular technique, for intracellular quantification of LM, different papers have displayed a slightly different step during CFU procedure, which may affect the accuracy of data published. This paper will analyze the method of CFU quantification of intracellular LM based on published studies, as well as provide some modified steps during CFU procedure to acquire more precise data. In accordance with providing an improved $\mathrm{CFU}$ protocol, some useful notes during immunefluorescence were also provided.

\section{MATERIALS AND METHODS}

\section{Bacteria preparation}

Three to four single bacterial colonies of LM strains (wild type 10403S, GFP-expressing LM (10403S) (Shen, Higgins, 2005) were added to $5 \mathrm{~mL}$ of Brain Heart Infusion/BHI broth, incubated at $37^{\circ} \mathrm{C}$ overnight in a rocking shaker at $250 \mathrm{rpm}, 37^{\circ} \mathrm{C}$ to obtain an $\mathrm{OD}_{600 \mathrm{~nm}}$ between 1.4 to 1.6 . The bacterial culture was then diluted $1 / 100$ in $10 \mathrm{~mL}$ of $\mathrm{BHI}$ broth, and further shaken in the rocking shaker for 2 hours (h) to obtain an $\mathrm{OD}_{600 \mathrm{~nm}}$ from 0.05 to 0.1 (Myers, Tsang et al. 2003). Bacteria were centrifuged at $3273 \mathrm{x} \mathrm{g}$ at $4^{\circ} \mathrm{C}$ for 10 minutes (min). The pellet was resuspended and diluted in prewarmed cell culture medium to obtain the desired multiplicity of infection (MOI) before adding to cells. For MOI check, LM inoculum was plated as 10 -fold serial dilutions $\left(10^{-3}, 10^{-4}, 10^{-5}\right)$ on $\mathrm{BHI}$ agar plates. These plates were incubated at $37^{\circ} \mathrm{C}$ from 24 to $48 \mathrm{~h}$, and colonies counted to determine colony forming units (CFU).

\section{Listeria monocytogenes infection of macrophages}

LM infection of the macrophage cell line
RAW264.7 was performed as described previously (Tilney, Portnoy, 1989). Cells were seeded into 48well plates at $1.5 \times 10^{5}$ per well overnight in complete medium, which contains Dulbecco's Modified Eagle Medium/DMEM supplemented with 10\% FBS, 2 mM L-Glutamine, 1 $\mathrm{mM}$ Sodium Pyruvate and $10 \mathrm{mM}$ HEPES buffer in DMEM (all GIBCO). Cells were infected with LM at MOI 5 and centrifuged at $335 \mathrm{x}$ g for $2 \mathrm{~min}$ at RT. Infected cells were incubated at $37^{\circ} \mathrm{C}$ and $5 \% \mathrm{CO}_{2}$. At $0.5 \mathrm{~h}$ post infection (p.i.), cells were washed twice with $50 \mu \mathrm{g} / \mathrm{mL}$ gentamicin diluted in DMEM to kill extracellular LM (Kuhn et al. 1988). Cells were washed twice with warm PBS and further incubated with complete DMEM supplemented with $5 \mu \mathrm{g} / \mathrm{mL}$ gentamicin to prevent continual reinfection of macrophages by LM released from dying cells. At different periods after infection, cells were washed once with $0.5 \mathrm{~mL}$ warm PBS and lysed in $1 \mathrm{~mL}$ of sterile $0.1 \%$ Triton $\mathrm{X}-100$ in PBS. Numbers of viable intracellular LM were determined by performing 10 fold serial dilutions and plating on $\mathrm{BHI}$ agar plates. Aliquots of $20 \mu \mathrm{L}$ of undiluted, $10^{-1}, 10^{-2}, 10^{-3}$ diluted lysate in PBS were spread on BHI agar plates (1.5\% agar). Plates were incubated at $37^{\circ} \mathrm{C}$ from 24 to $48 \mathrm{~h}$ and CFU was counted.

\section{Immunofluorescence}

Sterile glass coverslips $15 \mathrm{~mm} \phi$ (G420-15, ProSciTech) were put into each well of a 24 well plate. Macrophages were seeded at $2 \times 10^{5}$ cells per well in $350 \mu \mathrm{L}$ complete medium one day prior to infection. Macrophages were infected with LM at MOI 3 (1 macrophage: $3 \mathrm{LM})$. At $0.5 \mathrm{~h}$ after infection, cells were washed twice with $50 \mu \mathrm{g} / \mathrm{mL}$ gentamicin diluted in DMEM to kill extracellular LM. Cells were washed twice with warm PBS and further incubated with complete DMEM supplemented with $5 \mu \mathrm{g} / \mathrm{mL}$ gentamicin. At different time points after infection, cells were fixed by $4 \%$ paraformaldehyde diluted in PBS for $15 \mathrm{~min}$ at room temperature. Fixed cells then were washed twice with PBS and blocked for $1 \mathrm{~h}$ in blocking buffer ( $2 \%$ bovine serum albumin/BSA containing $0.1 \%$ Triton $\mathrm{X}-100 / \mathrm{PBS})$ at room temperature. After blocking, cells were washed three times with PBS and stained for $1 \mathrm{~h}$ with the primary antibody against CD11b-PE (diluted at 1:200) (Biosciences) to visualize macrophage surface membrane. Cells then were washed with PBS and stained with the secondary antibody Alexa flour 594conjugated donkey-anti-rabbit IgG $(5 \mu \mathrm{g} / \mathrm{mL}$, Abcam) for $1 \mathrm{~h}$ in the dark. Primary and secondary antibodies 
were diluted blocking buffer. To visualize polymerized actin, after fixation step, cells were stained with Alexa flour 467-conjugated Phalloidin $\left(6.6 \times 10^{-3} \mu \mathrm{M}\right)$ (Cell Signaling Technology). Cell nuclear was stained with 4', 6-diamidino-2-phenylindole dihydrochloride/DAPI (1 $\mu \mathrm{g} / \mathrm{mL}$, Molecular Probes). After staining, the coverslips were washed three times with PBS and one time with distilled water to remove residual salts. Coverslips were mounted with ProLong Gold Antifade Mountant (Life Technologies) and coverslip edges were sealed on microscope slides (S21102A Menzel) using clear nail polish. Microscopy slides were examined using an Olympus Epifluorescence inverted microscope IX73 (60 x magnification). Scale bars represent $10 \mu \mathrm{m}$.

\section{RESULS AND DISCUSSION}

\section{Determination of time point when macrophages take up LM}

Determination of a right time point when host cells just about complete the internalization of LM is important, as earlier than that point the bacteria still locate extracellularly but later than that point the intracellular bacteria are replicated or partially killed by the host. An uptake point was determined by the first washing time stated in the study. In fact, differential uptake time points were set up by different studies, which largely depending on whether host cells are phagocytic or non-phagocytic cells (e.g. Caco-2, Hela, MEF). In studies with host cells are macrophages, which rapidly engulf $\mathrm{LM}$ via phagocytosis pathway (Radoshevich, Cossart, 2017), uptake time is usually set up from at $30 \mathrm{~min}$ (Portnoy et al., 1988; Kuhn et al., 1988; Birmingham et al., 2007; Woodward et al., 2010) to $45 \mathrm{~min}$ (de Chastellier et al., 1994) after infection. In this study, uptake time point was observed since at $0.5 \mathrm{~h}$ post infection of macrophages (Figure 1A). At $0.5 \mathrm{~h}$ post infection, most of macrophages engulfed from $1-2$ bacteria per cell whereas at $2 \mathrm{~h}$ post infection, there are more bacteria per cell and most of cells contain more than 15 bacteria (Figure 1B). As the infection was halted at $0.5 \mathrm{~h}$ post infection by gentamicin wash, the increase number of bacteria at $2 \mathrm{~h}$ compared to $0.5 \mathrm{~h}$ indicates that at $2 \mathrm{~h}$ post infection, intracellular bacteria already multiply.

When host cells are non-phagocytic cells such as Caco-2, Hela, MEF, which internalize LM through receptor-mediated endocytosis (Cossart, Helenius, 2014), it requires at least $60 \mathrm{~min}$ for the cells to take up LM (Gaillard et al., 1987; Portnoy et al., 1988;
Py et al., 2007). However, in our LM infection assay of L929 cells, at $60 \mathrm{~min}$ after infection, majority of bacteria still bind to the cell membrane. Extension uptake time until $2 \mathrm{~h}$ post infection, intracellular LM was observed (Figure 2). Therefore, the uptake time point might be extended depending on the host cell types. To optimize the uptake, after adding bacteria onto host cells, the plate can also be centrifuged, as modified by Birmingham et al. (2007). In this study, after adding LM onto the cultured host cells, including macrophages and other non-phagocytic cells, the plate containing those infected cells were centrifuged at $335 \mathrm{x}$ g for $2 \mathrm{~min}$ at room temperature to synchronize the uptake.

\section{Using gentamicin at different concentrations for different purposes}

Gentamicin, which cannot go through mammalian cells, was largely used to kill extracellular or adherent LM not removed by the first washing step (Devenish et al., 1981). There are different concentrations of gentamicin used in LM infection assays. Whereas in most of studies, gentamicin at 5 , 10 or $50 \mu \mathrm{g} / \mathrm{mL}$ were added to the cell media during the experiment duration after washing (Pornoy et al., 1988; Kuhn et al., 1988; Woodward et al., 2010; Birmingham et al., 2007), other studies used gentamicin at 5 or $10 \mu \mathrm{g} / \mathrm{mL}$ to wash the extracellular bacteria in the first washing step (Py et al., 2007; Gaillard et al., 1987). It is demonstrated that to wash off adherent bacteria and prevent reinfection by bacteria released after cell burst, two concentrations of gentamicin can be used in the infection assay. Firstly, at $30 \mathrm{~min}$ post infection for host cells are macrophages or $60 \mathrm{~min}$ or so for other non-phagocytic cells, cells were washed twice with $50 \mu \mathrm{g} / \mathrm{mL}$ gentamicin diluted in DMEM to kill extracellular LM. Cells were washed twice with warm PBS and further incubated with media supplemented with $5 \mu \mathrm{g} / \mathrm{mL}$ gentamicin to prevent continual reinfection of host cells by LM released from dying cells.

Triton $\mathrm{X}-100$ diluted in PBS is used to release intracellular LM whereas distilled water (mQ water) unexpectedly killed further bacteria

At different periods after infection, cells were washed once with warm PBS and lysed in $0.1 \%$ Triton X-100 in PBS. To lyse the cell for the releasing of intracellular LM, several studies use sterile mQ water (Gaillard et al., 1987; Pornoy et al., 1988; Py et al., 2007; Woodward et al., 2010) whereas others 
used Triton X-100 (Kuhn et al., 1988; de Chastellier et al., 1994; Birmingham et al., 2007). For a more rapid lysing of host cells, ice-cold $0.1 \%$ Triton X-100 was efficiently used to lysethe cells after the final wash. It is nocticeble that the number of viable intracellular LM dropped significantly when lysing host cells in Triton X-100 diluted in mQ water for $1.5 \mathrm{~h}$ before plating. However, Triton X-100 diluted in
PBS did not kill more LM at $1.5 \mathrm{~h}$ compared to $0.5 \mathrm{~h}$. This suggested that LM cannot resist to water for long time incubation. Therefore, it will give a more reliable CFU data when using $0.1 \%$ Triton $\mathrm{X}-100$ diluted in PBS to lyse the cell than using $\mathrm{mQ}$ water, especially in large-scale experiments which require more extensive time for washing, lysing and plating the lysate.

A

DAPI/DNA

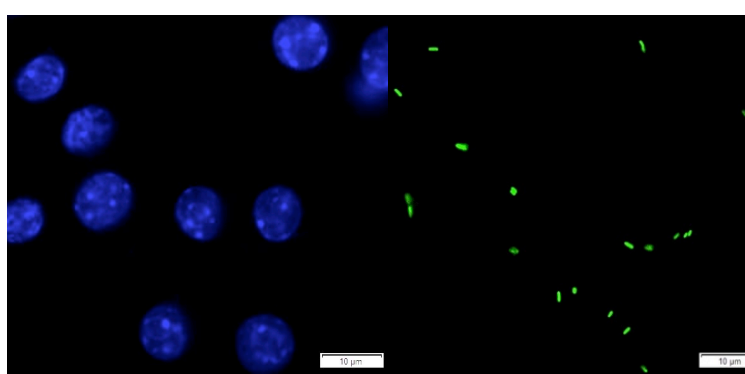

B

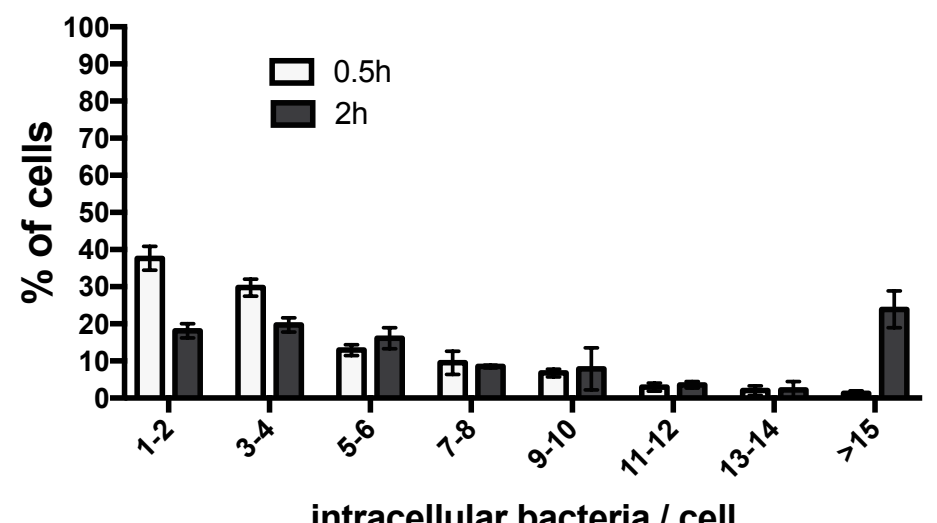

Figure 1. A. RAW264.7 mouse macrophages take up LM since at $0.5 \mathrm{~h}$ post infection. B. Display of bacteria numbers inside infected cells at $0.5 \mathrm{~h}$ and $2 \mathrm{~h}$ post infection. (A-B: Data are means \pm SEM from one experiment of the three, performed in triplicates, analyzed in Graphpad Prism).
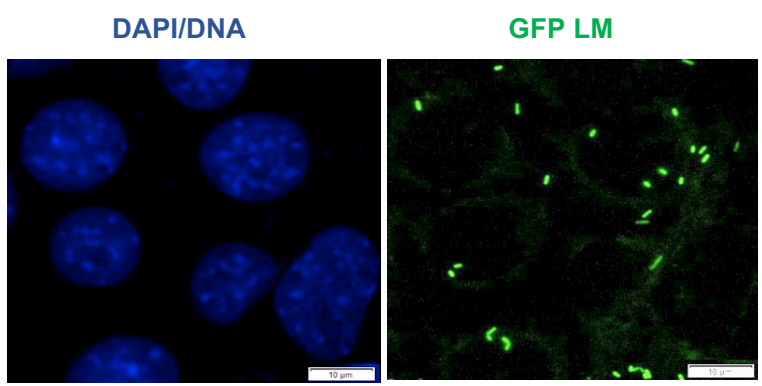

Cell polymerized actin

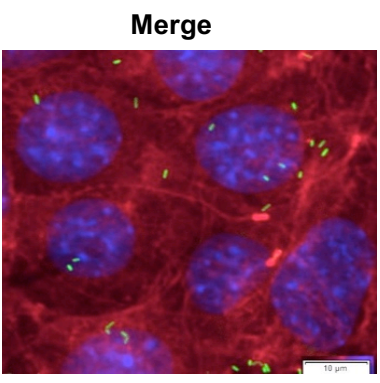

Figure 2. Listeria monocytogenes infection of L929 cells, uptake was determined at $2 \mathrm{~h}$ post infection. Intracellular bacteria were captured at $4 \mathrm{~h}$ post infection. 


\section{1\% Triton $X$ in PBS \\ $0.1 \%$ Triton $X$ diluted in $\mathrm{mQ}$ water}

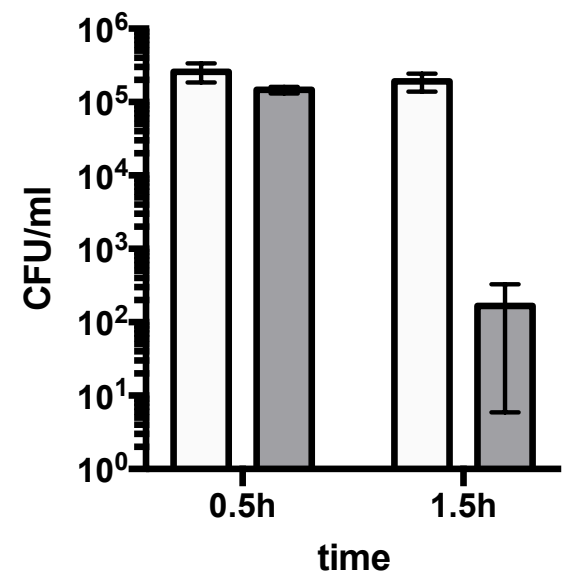

Figure 3. Decrease of viable LM in lysate when lysing the cells with $m Q$ water. RAW264.7 macrophages were infected by LM at MOI 5. Data are means \pm SEM from one experiment of the three, performed in triplicates, analyzed in Graphpad Prism.

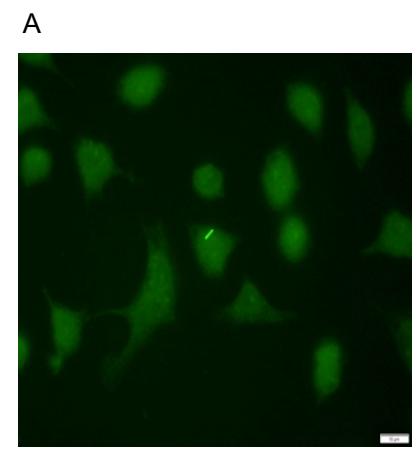

Methanol Fixation

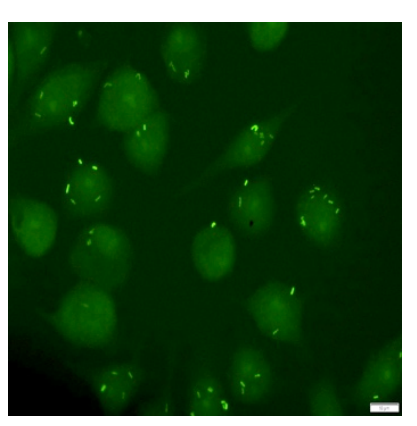

PFA fixation

B

DAPI/DNA

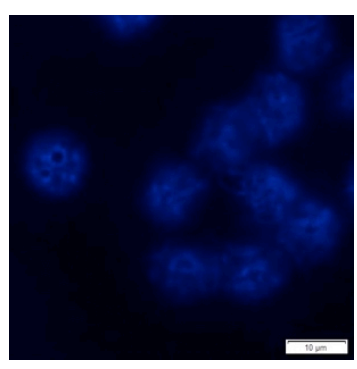

LM

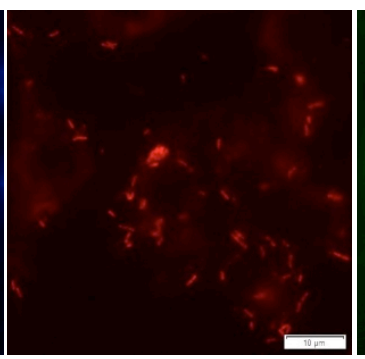

GFP channel

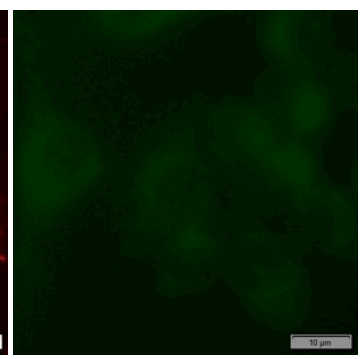

Merge

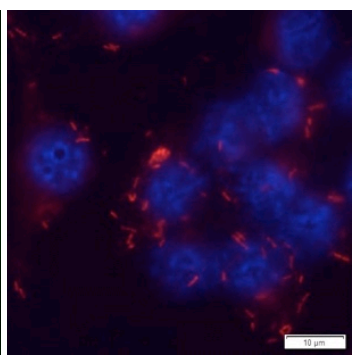

Figure 4. A. Methanol degraded GFP signal. B. LM can be stained using antibody against LM. A-B. RAW264.7 macrophages were infected with GFP-LM (A) or wild type LM (B) at MOI 3. LM was stained using primary antibody goat anti-Listeria (KPL, diluted at 1:100) and secondary Donkey Anti-Goat IgG H\&L (Alexa Fluorß 594) (Abcam, diluted at 1:400) 


\section{Using immunofluorescence technique to quantify} intracellular bacteria

Immunofluorescence imaging of bacteria is also a standard procedure allowing the quantification of intracellular bacteria. Preliminary studies utilized ethidium bromide to stain extracellular LM in red, which distinguished from the green-fluorescent intracellular LM in infected macrophages (Drevets, Campbell, 1991). This technique is fairly simple but it requires more time working with the microscope to switch from one light source or filter to another. With the modified protocol of gentamicin treatment, most of extracellular bacteria were washed off, leaving intracellular bacteria alive. RAW264.7 macrophages were infected with LM expressing GFP. After $0.5 \mathrm{~h}$, cells were washed with gentamicin $(50 \mu \mathrm{g} / \mathrm{mL}$ in PBS) to remove extracellular bacteria and fresh medium containing gentamicin $(5 \mu \mathrm{g} / \mathrm{mL})$ was replaced and cultures maintained until the time of interested. Cells were fixed with paraformaldehyde $4 \%$ and stained with DAPI to observe nuclear DNA and with other markers to visualize the host cell membrane or boundary. In this study, CD11b, which expressed on the macrophage surface, was used to stain the cell (Figure 1A). In addition, Phalloidin can also be used to stain polymerized actin, which allowing the visualization of the host cell cytoskeleton (Figure 2). It is important to notice that to observe GFP-LM, cells should be fixed with paraformaldehyde, not with absolute methanol. Methanol is also a fixable reagent which is commonly used in immunofluorescence microscopy; however, methanol promptly ablates the fluorescence signal of GFP protein thus intracellular GFP-LM cannot be observed with methanol fixation (Figure 4A). To stain other proteins which require methanol fixation, it is advisable to use antibody to stain LM instead of using GFP-LM for the infection (Figure 4B).

\section{CONCLUSION}

This study gives an overview of using CFU and immunofluorescence as standard techniques to quantify intracellular LM. Published papers have been using different protocols for in vitro infection of LM and CFU performance, making it difficult to interpret the data. During macrophage infection of LM, uptake time was determined at $0.5 \mathrm{~h}$ post infection. Different concentrations of gentamicin were used during the infection assay to kill extracellular bacteria and prevent continual infection effectively. To lyse the host cells and release intracellular bacteria for colony counting, PBS should be used in charge of $\mathrm{mQ}$ water in large scale experiments. In immunofluorescence, LM can be visualized by using either the LM expressing GFP, or an antibody against LM. To observe intracellular GFP-LM, cells should be fixed with paraformaldehyde as methanol will rapidly quench the GFP protein.

Acknowledgment: This project is supported by Australia Awards Scholarships. I sincerely thank Associate Professor Antje Blumenthal and all members of Blumenthal lab, Diamantina Institute, School of Medicine, the University of Queensland for supporting me during my $\mathrm{PhD}$.

\section{REFERENCES}

Becattini S, Pamer EG (2017) Multifaceted Defense against Listeria monocytogenes in the Gastro-Intestinal Lumen. Pathogens 7: 1.

Birmingham CL, Canadien V, Gouin E, Troy EB, Yoshimori T, Cossart P, Higgins DE, Brumell JH (2007) Listeria monocytogenes evades killing by autophagy during colonization of host cells. Autophagy 3: 442-451.

Cossart P (2011) Illuminating the landscape of hostpathogen interactions with the bacterium Listeria monocytogenes. Proceedings of the National Academy of Sciences, 108: 19484-19491.

Cossart P, Helenius A (2014) Endocytosis of viruses and bacteria. Cold Spring Harbor Perspectives in Biology 6: a016972.

de Chastellier C, Berche P (1994) Fate of Listeria monocytogenes in murine macrophages: evidence for simultaneous killing and survival of intracellular bacteria. Infection and Immunity 62: 543-553.

de Noordhout CM, DevleesschauwerB, AnguloFJ, Verbeke G, HaagsmaJ, KirkM, HavelaarA, Speybroeck N (2014) The global burden of listeriosis: a systematic review and meta-analysis. The Lancet Infectious Diseases 14: 1073-1082.

Devenish JA, Schiemann DA (1981) HeLa cell infection by Yersinia enterocolitica: evidence for lack of intracellular multiplication and development of a new procedure for quantitative expression of infectivity. Infection and Immunity 32: 48-55.

Drevets DA, Campbell PA (1991) Macrophage phagocytosis: use of fluorescence microscopy to distinguish between extracellular and intracellular bacteria. Journal of Immunological Methods 142: 31-38.

Ferreira M, Almeida A, DelgadilloI, Saraiva J, Cunha Â (2016) Susceptibility of Listeria monocytogenes to high 
pressure processing: A review. Food Reviews International 32: 377-399.

Gaillard JL, Berche P, Mounier J, Richard S, Sansonetti P (1987) In vitro model of penetration and intracellular growth of Listeria monocytogenes in the human enterocyte-like cell line Caco-2. Infection and Immunity 55: 2822-2829.

Hamon M, BierneH, Cossart P (2006) Listeria monocytogenes: a multifaceted model. Nature Reviews Microbiology 4: 423.

Kuhn M, Kathariou S, Goebel W (1988) Hemolysin supports survival but not entry of the intracellular bacterium Listeria monocytogenes. Infection and Immunity 56: 79-82.

Myers JT, Tsang AW, Swanson JA (2003) Localized reactive oxygen and nitrogen intermediates inhibit escape of Listeria monocytogenes from vacuoles in activated macrophages. The Journal of Immunology 171: 54475453.

Portnoy DA, Jacks PS, Hinrichs DJ (1988) Role of hemolysin for the intracellular growth of Listeria monocytogenes. Journal of Experimental Medicine 167: $1459-1471$

Py BF, Lipinski MM, Yuan J (2007) Autophagy limits Listeria monocytogenes intracellular growth in the early phase of primary infection. Autophagy 3: 117-125.

Radoshevich L, Cossart P (2018) Listeria monocytogenes: towards a complete picture of its physiology and pathogenesis. Nature Reviews Microbiology 16: 32.
Ricchi M, Bertasio C, Boniotti MB, Vicari N, Russo S, Tilola M, Bellotti MA, Bertasi B (2017). Comparison among the quantification of bacterial pathogens by qPCR, dPCR, and Cultural methods. Frontiers in Microbiology 8: 1174.

Shen A, Higgins DE (2005) The 5' untranslated region-mediated enhancement of intracellular listeriolysin $\mathrm{O}$ production is required for Listeria monocytogenes pathogenicity. Molecular Microbiology 57: 1460-1473.

Swarts AJ, Hastings JW, Roberts RF, Von Holy A (1998) Flow cytometry demonstrates bacteriocin-induced injury to Listeria monocytogenes. Current Microbiology 36: 266270.

Tilney LG, Portnoy DA (1989) Actin filaments and the growth, movement, and spread of the intracellular bacterial parasite, Listeria monocytogenes. The Journal of Cell Biology 109: 1597-1608.

Traunšek U, Toplak N, Jeršek B, Lapanje A, Majstorović T, Kovač M (2011) Novel cost-efficient real-time PCR assays for detection and quantitation of Listeria monocytogenes. Journal of Microbiological Methods 85: $40-46$

Vázquez-Boland JA, Kuhn M, Berche P, Chakraborty T, Domínguez-Bernal G, Goebel W, González-Zorn B, Wehland J, Kreft J (2001) Listeria pathogenesis and molecular virulence determinants. Clinical Microbiology Reviews 14: 584-640.

Woodward JJ, Iavarone AT, Portnoy DA (2010) c-di-AMP secreted by intracellular Listeria monocytogenes activates a host type I interferon response. Science 328: 1703-1705.

\title{
KỸ THUẬT CẢI BIẾN TRONG ĐỊNH LƯợNG NHIẼ̃M VI KHUẨN LISTERIA MONOCYTOGENES NỘI BÀO IN VITRO
}

\author{
Trần Thanh Thảo ${ }^{1,2}$, Nguyễn Thị Hà \\ ${ }^{I}$ Truòng Đại học Cần Tho \\ ${ }^{2}$ Viện nghiên cứu Diamantina, Khoa y học, Truờng Đại học Queensland, Australia.
}

\section{TÓM TẮT}

Nhu cầu về các phương pháp tin cậy để định lượng vi khuẩn nội bào in vitro ngày càng gia tăng. Bên cạnh những phương pháp hiện đại như PCR và flow cytometry, các phương pháp truyền thống như đếm khuẩn lạc và nhuộm huỳnh quang vẫn được sử dụng phổ biến. Trong phương pháp đếm khuẩn lạc, các sai khác trong quy trình thực hiện giữa các tài liệu xuất bản làm cho kết quả thí nghiệm không đồng nhất giữa các công trình nghiên cứu. Bài báo này đánh giá những tồn tại nhằm cải thiện các phương pháp hiện hành trong định lượng vi khuẩn nội bào Listeria monocytogenes $(\mathrm{LM})$. Nghiên cứu này xác định thời gian để $\mathrm{LM}$ bị thực bào sẽ tuỳ vào loại tế bào chủ. Cụ thể nếu tế bào chủ là tế bào bạch cầu RAW264.7 thì thời gian thực bào là 0,5 giờ, còn ở tế bào sợi L292 là 2 giờ kể từ thời điểm tế bào bắt đầu nhiễm khuẩn. Để giết các tế bào vi khuẩn không bị thực bào một cách hiệu quả, kháng sinh gentamicin với nồng độ cao và thấp được sử dụng xen kẽ. Gentamicin nồng độ cao sẽ giết các vi khuẩn không được thực bào trong khi gentamicin nồng độ thấp sẽ được bổ sung vào môi trường nuôi cấy để ngăn ngừa tế bào chủ tiếp tục bị nhiễm trong thời gian nuôi cấy. Để định lượng chính xác số lượng LM sống trong tế bào chủ đối với các thí nghiệm quy mô lớn, phosphate-buffered saline/PBS cần được sử dụng để nghiền tế bào thay cho nước siêu sạch $(\mathrm{mQ})$ vì nước siêu sạch có thể giết vi khuẩn ngoài ý 
muốn. Trong thí nghiệm nhuộm huỳnh quang, $\mathrm{LM}$ có thể được quan sát bằng cách sử dụng dòng vi khuẩn phát quang hoặc dùng kháng thể huỳnh quang để nhuộm vi khuẩn. Khi sử dụng dòng vi khuẩn phát quang, tế bào chủ cần được cố định bằng paraformaldehyde thay vì dùng methanol vì methanol sẽ làm hư hại các protein phát quang. Các kết quả của bài báo này mang lại nhiều thông tin tham khảo thiết thực trong nghiên cứu về tế bào học và bệnh truyền nhiễm.

Từ khoá: đại thực bào, đơn vị khuẩn lạc, Listeria monocytogenes, nội bào, vi khuẩn 